\title{
CODE-MIXING OF JAVANESE LANGUAGE AND BAHASA INDONESIA IN THE FRIDAY PRAYER SERMON AT MIFTAHUL HIDAYAH MOSQUE, PENDEM VILLAGE, CITY OF BATU, EAST JAVA
}

\section{CAMPUR KODE BAHASA JAWA KE BAHASA INDONESIA DALAM KHUTBAH JUMAT DI MASJID MIFTAHUL HIDAYAH DI DESA PENDEM, KOTA BATU, JAWA TIMUR}

\author{
Afif Ikhwanul Muslimin \\ Universitas Islam Negeri Mataram \\ Ponsel: 081808304480; Pos-el:afifikhwanulm@uinmataram.ac.id
}

Naskah Diterima Tanggal: 2 Juli 2020; Direvisi Akhir Tanggal: 1 Desember 2020; Disetujui Tanggal: 9 Desember2020 DOI: https://doi.org/10.26499/mab.v14i2.400

\begin{abstract}
Code-mixing phenomenon which appears in different settings and contexts creates interest for investigation. This research is aimed to analyze the elements of code mixing in Friday prayer sermon, the reasons underlying speaker to mix code, and the responses of audience. This is a qualitative research by implementing content analysis. Based on the analysis, the elements of code mixing in the sermon were in the form of words, phrases, and clauses. The reasons causing speaker mixing the code are making the sermon easy listening, making his sermon accepted, understanding listener that old man preferred local language in sermon, matching sermon with social condition, making himself accepted, making ease to deliver the sermon, making sermon more communicative, and making the sermon get in touch with the listeners. Then, based on the questionnaires which were given to 25 respondents, there were 22 people understood the sermones. However, 10 people of them said that the sermones should be delivered in Bahasa Indonesia only. They thought that the sermon would be more easy listening, more understandable, and created more comfortable listening. On the other hand, they thought many listeners were the outsiders of the village. Hence, it is concluded that phenomenon appears to consider context, goal, and audience.
\end{abstract}

Keywords: code; code mixing; sermons; friday prayers

\begin{abstract}
Abstrak
Fenomena campur kode yang muncul pada lingkup dan konteks yang beraneka ragam menjadi menarik untuk diteliti. Penelitian ini bertujuan untuk menganalisis unsurunsur pencampuran kode dalam pidato sholat Jumat, alas an penceramah mencampur kodea, dan mengetahui respon pendengarnya. Ini adalah penelitian kualitatif dengan menerapkan analisis konten. Berdasarkan analisis, unsur-unsur pencampuran kode dalam pidato adalah dalam bentuk kata, frasa, klausa, dan kalimat. Alasan penyebab penceramah mencampur kode adalah untuk membuat jamaah lebih mudah mendengarkan pidatonya, membuat pidatonya diterima oleh pendengar, memahami penden-
\end{abstract}




\section{Code Mixing in Javanese Language...}

gar bahwa orang tua merasa nyaman jika pidato itu disampaikan dalam bahasa lokal, mencocokkan pidato dengan kondisi sosial, membuat dirinya diterima oleh pendengar, mempermudah pembicara menyampaikan pidato, membuat lebih komunikatif, dan menyentuh lebih dalam pendengar. Kemudian, berdasarkan analisis kuesioner yang diberikan kepada 25 responden, ada 22 orang yang memahami pidato tersebut. Tetapi, 10 orang dari mereka mengatakan bahwa pidato harus disampaikan dalam Bahasa Indonesia saja. Sepuluh orang itu berpendapat bahwa pidato akan lebih mudah didengarkan dan dipahami, dan juga penggunaan bahasa Indonesia dalam pidato membuat pendengar merasa lebih nyaman untuk mendengarkan. Di sisi lain, mereka mengira banyak pendengar adalah orang luar desa. Sehingga, dapat disimpulkan bahwa fenomena itu terjadi karena memperhatikan kontek, tujuan, dan pendengar.

Kata kunci: kode; campur kode; pidato; salat Jumat

\section{Introduction}

Nowadays, as the time goes by, many people have forgotten their mother tongue. They think that Bahasa Indonesia is more suitable to be used in every occasion because Bahasa Indonesia is the national language of Indonesia (tirto.id, 19 Juli 2019). Such kind of reality mostly happens in many big cities in Indonesia, but not in the village or rural areas. The people in the village or rural areas still use their regional language as their daily means of communication because they feel uncomfortable if they speak in Bahasa Indonesia. Sometimes, they also use their local language in a formal occasion, such as when they have to deliver a religious sermon in the mosque every Friday.

Generally, someone who has to deliver a sermon among the Javanese people, especially when it is delivered in a village, he will speak in Javanese, or sometimes, he will combine both Javanese and Bahasa Indonesia. Moreover, there should be some reasons behind the combining. The combining of two languages in speaking, in the sociolinguistics study, is known as code- mixing or code-switching. Hudson (2012) states that code mixing occurs when the speaker mixes the different languages in the same utterances, and code switching happens when a single speaker uses different varieties at different time. They produce some codes because they want to communicate with other easily, fluently, and the information can be transferred well.

The code-mixing phenomenon was also found in sermon that was delivered in Miftahul Hidayah mosque in Pendem village in Jum'atan prayer (friday prayer). In this sermon, the speaker mixes three languages. They were Arabic, Bahasa Indonesia, and Javanese language. Arabic was used while the speaker read the openings and the endings of the sermon containing ayat, hadist, etc., originally written in Arabic. The speaker used Bahasa Indonesia as the language in the content of the sermon and of course there was mixing of Javanese language to Bahasa Indonesia. The speaker sometimes included Javanese language term, and words into Indonesian sermon, in which elements of one language are used within a sentence or discourse in 
another language, and this phenomenon is called code mixing (Nababan, 1997)

Sometimes it will be more interesting to listen someone who is speaking by employing code mixing. In daily life, it is not strange that there are some Javanese people using this way. They combine the vocabulary of a language into other language or only using part of a language into other language. As the example, Javanese tend to mix Javanese language in Bahasa Indonesia sentences as the influence of their mother tongue language.

There have been researches regarding the application of code mixing in different setting. First, Dewi, et. al. (2017) who analysed the English department students' code mixing in instagram mentioned that the dominant code was in lexical level. The students' reasons were about showing their English capability and to be up todate. Second, Kustati (2014) stated that both teacher and students in EFL classroom applied code mixing in the level of words and sentence. Their reason was to overcome the lack of language. Third, Pratama (2014) showed that 9MM gamers tended to mix codes in lexical and sentences levels. Then, he suggested investigating the reasons why gamers mixed those codes. Based on those researches, it can be noticed that none of them discussing code mixing phenomenon in traditional or society setting while code mixing is topics in sociolinguistics that really relevant to choose social event as the setting for research. Then, none of them discussed the reasons of speaker to mix the code based on Hymes (in Wardaugh, 2002) theory, as it is the genuine theory for understading the reasons of code mixing.

Regarding the gap of the previous researches, it is interesting to understand more about this code-mixing and codeswitching which happens in everyday situation in real social live. The unclear reason of using code-mixing makes the researcher curious to find out the most reasonable reason behind this. That's why the researcher chooses a title "Code Mixing of Javanese Language into Bahasa Indonesia in Friday Prayer Sermon (January31 ${ }^{\text {st }}, 2020$ ) by a Moslem Scholar in Miftahul Hidayah Mosque in Pendem Village"

\section{Theoretical Basis}

\subsection{Previous Studies}

There have been some previous studies regarding the phenomena of code mixing in different contexts. Ramadhan (2015) states that inside Ranah 3 Warna Novel, code mixing appeared in two forms, they are internal and external code mixing. The causes why the author implemented them were the author's background, taking someone's quotations, the goal of the author, and understanding the background of the readers. Budi, et. al. (2017) analysed the code-mixing phenomenon in 
Kaskus.com conversation. Inside the forum, he mentioned that only few codes mixing appeared since the authors or kaskus.com users thought that the most of users were incompetence to understand multiple language information. Another codemixing research was conducted by Prasetyo (2014) who mentioned that SBY, the president of Indonesia, employed code mixing during his sermon because of considering some factors such as function, topic, participant, and setting. Lastly, Fadila (2016) stated that code mixing also occurred during the presidential debates in 2014. She said that the cuases of the code mixing were to show the social statues, and to substitute non-congruent Indonesia translation word. The aforementioned researches depicted only few backgrounds that trigger the user of code mixing regarding the Hymes theory. Moreover, only some of them discussed the position of code mixing syntactically. Finally, none of them were discussing the code-mixing phenomena in daily events.

\subsection{Theoretical Framework}

Wardaugh (2002) argues that "code refers to a language or a variety of languge." In addition, according to Fraenkel (1982) "a code is method forconveying a message with the help of symbols arbitrarily, though systematically, chosen to substitute for other widely understood signals. A code, though arbitrary as a system, must be well prepared and useful in order to serve its purpose.
Certainly, language is such a code." So, we can conclude that code is used to make the communication clearly understood although it seems strange.

There are some definitions of code mixing. According to Holmes (2001) code mixing suggests that the speaker mix up code because of incompetence, whereas the switches are very well-motivated in relation to symbolic or social meanings of two codes. In this suggestion, bilingual does not know exactly the use of code mixing or the theory related to it before. Meanwhile, according to Fasold (1984) code mixing is a kind of language choice where pieces of one language are used while a speaker is basically using another language. $\mathrm{He}$ assumes that it is only pieces of one language to be mixed in another language. So, the using of two languages are in one language. In the end, Code mixing is the use of the elements of one language within a sentence or discourse in another language (Nababan, 1997).

The concept of code mixing based on those three theories is elaborated further as using two languages or more in which there are pieces taken from one language and inserted into other language, which has the characteristic of interference. The interference occurs on the aspects of words, clause, idiom, etc as being discussed by Hanif (2016) as follows:

$\checkmark \quad$ Poro jama'ah sholat Idul Adha ingkang berbahagia. (To every 
listener of Idul Adha who are in happiness)

$\checkmark \quad$ Lan akhiripun pada hari ketiga. (And finally, on the third day)

For the example above, the use of Bahasa Indonesia in Idul Adha sermon 1428 $\mathrm{H}$ is mixed by Javanese language either in vocabulary, or in morphology. The first example, there is an interference in vocabulary by replacing "Para" with "Poro" means "To every" and "Yang" with "Ingkang" means (who or that). While in the second example there is morphology interference, such as adding suffix /-pun/ in the word "Akhiripun" that means "In the end". There is also interference in vocabulary in the second example, that is replacing conjunction "Dan" with "Lan" meaning "And".

In society, sometimes a group of people like to mix some code into other language in making conversation. They feel more comfortable and enjoy getting conversation with their group while doing code mixing. In some cases, code mixing raises up their social status. Speaker is usually fluent in both language and regularly uses both in the course of their daily routines (Gumperz. 1982). Holmes (2001) assumes that bilingual often finds it easier to discuss a particular topic in one language rather than another.

In addition, the society often confused with code mixing, and it is important to distinguish code mixing and code switching as both often happen simultaneously. Code switching is a conversational strategy used to establish, cross or destroy group boundaries; to create, to evoke, or change interpersonal relations with their rights and obligations. Moreover, there are two kinds of code switching: situational code switching and metaphorical code switching. Situational code switching occurs when the languages used change according to the situation in which the conversants find themselves: they speak one language in one situation and another in different one. One topic change involved. When a change of topic requires a change in the language used, we have metaphorical code switching. Code mixing occurs when conversant use both languages together to extent that they change from one language to the other in the course of single utterance. (Wardhaugh, 2002)

In order to give clearer definition about code mixing, Saville-Troite (2008) explains the distinction between intra-sentential (Code Mixing) and inter-sentential (code switching), below:

a. Intra-sentential or code mixing is a switch typically occurs within a specific clause or sentence. Example: "Estaba snowing"

b. Inter-sentential or code switching is a switch that occurs between a clause or sentence boundary. 
Example: "Dejo paner el tender.

Thank you."

Code mixing is the combination of elements from two languages in a single utterance. Saville Troike (2008) states that "The elements of code mixing involve the utterances in a single noun from other language, a noun phrase, a verb phrase, an independent clause, and a tag question." Meanwhile, Hoffman (1991) reports that "The elements of code mixing transferred from other language are mostly in the form of Function words, article, prepositions, conjunctions, and adverb." According to Holmes (2001) suggest the code-mixing syntactical elements, which involve noun in the subject and object positions, verb phrase, preposition phrase or verb, adjective or adverb, and interjection. Here are several examples of code-mixing syntactical elements given by Brice (1999) are:

a. A noun

"M., sitienes ocho balloons y uno se revienta, cuanto; vas a tener?"

(If you have eight balloons and one burst, how many will you have?)

b. Prepositional phrase

"Do you have one of these en $s u$ casa?"

(In your house?)

c. Adverb

"Did you read it, si? (Yes)

d. Verb

"Inverno, remember, inverno."

(Winter, remember, winter) e. Adjective

"The acuerdas lo qué quleres dearless?'

(Do you remember the less means?)

f. Verb phrase

"Harmful, como a dañar algo."

(Like to damage something)

g. Interjection

"You're done, adios" (Goodbye)

While based on Setyaningsih (2005) in A Study on Code Mixing in the Novel "Ca-Bau-Kan" by Remy Sylado, there are four elements in code mixing. They are: (Indonesian and Javanese code mixing)

$\checkmark$ Words, for example

lan, ingkang, poro, dados, dipun,

etc.

$\checkmark$ Phrases, for example

inggih puniko, dinten meniko, etc.

$\checkmark$ Clause, for example sedinten sak sampunipun ngipi, etc.

$\checkmark$ Sentence, for example : $\quad k a d o s$ ingkang sampun dipun firmanaken kalian Tuhan YME wonten surat...

There are so many factors that can influence someone to use code mixing in his speaking. Hymes (in Wardhaugh, 2002:242-244) presents eight factors in influencing the occurrence of code choice. He used the word SPEAKING as an acronym for the various factors, they are:

1. The setting and scene 
The setting refers to the time and places in which the sermon takes places. Meanwhile, the scene is the abstract psychological setting or the cultural definition of the occasion.

2. The participants

Participants refer to the speaker and the listener or between the addresser and the addressee.

3. Ends

Ends refer to the conventionally recognized and expected outcomes of an exchange as well as to the personal goal that participants seek to accomplish on particular occasions.

4. Act Sequence

Refers to the actual form and content of what is said. The precise of word use, how they are used, and the relationship of what is said to the actual topic at hand.

5. Key

Refers to the tone, manner or spirit, in which a particular message is conveyed; serious, precise, pedantic, mocking, etc. The key may also be marked non-verbally by certain kinds of behavior, gesture, posture, and event.

6. Instrument
Instrument refers to the choice of channel lack oral, written, telegraphic, and to the actual forms of sermon employed, such as the language, dialect, code, or register that is chosen.

7. Norms of Interaction and Interpretation

Refers to the specific behavior and properties that attached to speaking and also to how these may be viewed by someone who doesn't share, i.e. loudness, silence, gaze return, etc. For example, there are certain norms of interaction with regard to church services and conversing with stranger.

8. Genre

Genre refers to clearly demarcated type of utterance such things as poems, proverbs, riddles, sermons, prayers, lectures, and editorial.

Meanwhile, Tripp (in Grosjean, 1982) presents four main factors, influencing the occurrence of code choice. They are:

1. The setting and Situation

In formal situation as certain setting the standard language is still used. Code switching and code mixing also occur in formal situation, but it occurs less in formal situation and it is 
depending on whom they speak to or the roles in their interaction.

2. Participants Participants convey sex, age, occupation, socio-economic status, origin, ethnicity, and their roles in relation to one another.

3. Topic or Purpose

One speaker may switch or mix the codes if she or he talks about the topic or she or he has certain purpose in his or her sermon, because people switch or mix the language if they can't find an appropriate words or expressions or when the long translation for the vocabulary is needed.

4. Function of Interaction

One function, status rising, has been found to play an important role in a number of different situations such as greeting, thanks, apology, and so on.

Both Hymes and Tripp actually have the same opinion toward the factors influencing the occurrence of code-choice even if it is presented in two different ways. Hymes explains the factors in more detailed way. Then, this research would use both of them as the basis of analysis of factor cuasing the Friday prayer sermon speaker employed code mixing during the sermon.

\section{Research Method}

The present research employed qualitative research. Denzin and Lincoln which is quoted by John W. Creswell (2016) states that qualitative research is multi method in focus, involving an interpretive, naturalistic approach to its subject matter. This means that qualitative researchers study these things in their natural setting, attempting to make sense of or interpret phenomena in terms of the meanings people bring to them.

The researcher chose content analysis as the type of the research. Kimberly (2014) states that content analysis a research tool used to determine the presence of certain words, themes, or concepts within some given qualitative data (i.e. text). Using content analysis, researchers can quantify and analyze the presence, meanings and relationships of such certain words, themes, or concepts. Researchers can then make inferences about the messages within the texts, the writer(s), the audience, and even the culture and time of surrounding the text. In the present research, the research analyzed the data which was acquired from the transcription of the sermones, the transcription of the interview, and the result of the questionnaires based on Hymes' and Tripp's theory to do triangulation.

The data sources of this study is a Friday prayer sermon which is delivered in Miftahul Hidayah mosque in Pendem Village, Batu on January $31^{\text {st }}$, 2020. Second, 
the researcher gave some listeners questionnaire related to their responses of the use of code mixing in the sermon. Before that, the researcher asked the guard of the mosque about the 25 people who frequently go to the mosque for praying and listening to the sermon as the representatives of the sample. Those 25 people are coming from the same "Dusun" that is "Dusun" Pendem. It is because the people who frequently go to Miftakhul Hidayah mosque for praying and listening to the sermon are only that people. Then, the data are the utterances in the sermones which contain code mixing, the result of the interview, and the result of the questionnaires.

The methods that were used to collect the data for this research were:

a. Documentation

In this method, the researcher recorded a Friday prayer sermon (January $31^{\text {st }}, \quad 2020$ ) which was delivered in Miftahul Hidayah mosque in Pendem village, Batu. Then, the researcher transcribed those sermones. Finally, the researcher identified the element of code mixing which could be found in the transcription. On the other hand, the researcher also transcribed the record of the interview with the speaker to find out the reasons why he mixed some codes in the sermon. b. Interview

The researcher interviewed the speaker of the sermon in order to find out the reason of using code mixing. Furthermore, the researcher knew whether it was necessary or not to use code mixing in the sermon based on the data obtained by means of questionnaires.

c. Questionnaires

The close-ended questionnaires were distributed to 25 respondents' who frequently went to Miftakhul Hidayah mosque for praying and listening to the sermon. It contained respondents' profiles, statements showing respondents' experience listening code mixing in Friday sermon, and respondents' perceptions toward the use of code mixing. The questionnaire was validated by the respondents were chosen based on the suggestion of the guard of Miftakhul Hidayah mosque and they were the residents of Dusun Pendem.

\section{Discussion}

The present research was aimed at investigating the elements of codemixing phenomenon in Friday prayer sermon, the factors triggering the speaker to employ code-mixing, and the responses of the audiences on the use of code-mixing in Friday prayer sermon. 


\subsection{The Elements of Code Mixing in a Friday Prayer Sermon}

The mixing of the code in a Friday Prayer Sermon (January $31^{\text {st }}, 2020$ ) which was happened was in the form of word, phrase, and clause. The detail findings are as follows

Word: ingkang (which/that); umumipun (generally); utawi (or); ananging (but); tiang (I); wonten (exist, there is); keranten (since); niku (that); maksudtipun (meaning); senaoso (although); dipun (is/are+past participle...passive); kanjeng (the majesty); meniko (that); ugi (also); puniko (that); poro (all); saking (from); kito (we); kalian (you); ningkataken (to increase); soho (also); and mugi-mugi (hopefully).

Phrase: dumateng ngarsanipun (to the majesty); monggolah kito (let us together); siang puniko (this afternoon); ingkang arupi (which is in form of); inggih puniko (that is); kito sedoyo (all of us); ingkang pundi (which one); ugi nyiptaaken (also creates); ingkang sampun (which has/have...); ingkang mboten (which is/are not...); contonipun keranten (the example because of...); duko niku (does not know that...); ingkang lintu (another thing); ananging kito (but, we); niku piambak (that is alone); saking gusti (from the Lord); ngeraos penat (feeling bored); ingkang artosipun (which means); tiang puniko (that person); dumateng ngarsanipun (toward the majesty); menungso niku (that person); puniko saget (that is able to...); ten ngrikilah (here is); kedah dipun (should be); ugi wonten (also there is); ten ngrikilah (here is); niku saget (it can); kados dawuhipun (as the words of); and ingkang mboten (which is not)

Clause: Kulo berwasiat dumateng (I deliver my will to); sedoyo punopo ingkang sampun dipun (all things that has/have been...); ugi nebihi larangan-laranganipun (also to avoid His prohibitions); wekdal puniko kito sedoyo (at the time we are...); nafsunipun menungso niku mboten (human desire is not); kalian sampun dipun ciptaaken menungso (also, it has been created human being); menungso niku dipun ciptaaken (human is created); puniko menungso nglampahi ingkang (the human does something which...); punopo ingkang dipun (something which is...); ingkang dadosaken awonipu kelampahan utawi (which makes bad deed or); tiangtiang ingkang angsal (the people who get); kados mekaten saget (such thing that can...); manahipun tansah enget dumateng ngarsanipun (the heart always remember to the majesty); keranten tiang ingkang sampun (since someone who has...); ingkang condong dumateng (which tends to); supados kito saget (in order to be able to); wonten dunyo mboten namong damel (having money not only for); ugi mboten namung damel (also, not only for); puniko ugi saget (that is also possible to); ingkang wonten lebetipun manah kito sedoyo (which is in our hearts); kados ingkang sampun dipun dawuhaken (as has been said); milo saking meniko (consequently); ingkang dipun riwayataken kalian (as stated by); 
ingkang saget kito (that we can); saget nebihaken kito sedoyo saking punopo ingkang dadosaken (able to keep us from something that creates); kulo lan panjenengan sedoyo (I and all of you); and wonten manah kulo lan penjenengan sedoyo (my heart and yours).

\subsection{The Factors that Encourage the} Speaker to Use Code Mixing in His Sermones

According to Hymes (in Wardhaugh, 2002) there are eight factors which can cause the speaker to mix the code. While according to Tripp (in Grosjean, 1982), there are only four factors which cause the speaker to mix the code. As the result, the researcher will use Tripp's theory because her theory is more detailed and make the researcher observe more easily the factors that cause someone to mix the code.

Based on the interview which had done with the speaker, we could find that there were some reasons why the speaker mixed the code. The reasons are:

1. To make the listeners listen more easily his sermon

In the interview the speaker says "Jika menggunakan bahasa Jawa itu akan lebih....ee... mudah dimengerti oleh mereka"(Means, if using Javanese language it will be better...ee...easier to be understood by them"). It shows that the speaker in the process of making the sermon, has thought first about the social condition of the people near Miftakhul Hidayah mosque.

2. To make his sermon accepted by the listener

The speaker in the interview said "Soalnya kalau pakai bahasa Indonesia saja, nanti akhirnya "Oh arek iku rek, kok pake bahasa Indonesia dewe, kok piye jadi ga enak" (Means "if I only use Bahasa Indonesia, resulting "Oh, this boy, why he uses only Bahasa Indonesia, $I$ think it is not comfortable"). He understands that not all the listeners of his sermon enjoy, understand, and use Bahasa Indonesia in their daily life. In the end, the speaker wants the listener to remember what he has spoken to them during the sermon.

3. To understand the listener that some old man will feel comfortable if the sermon is delivered in Javanese language.

While the speaker was making his sermon, he thought that his sermon would be heard by some old man. The old man in Pendem village use Javanese language in their daily life. They will feel more comfortable if someone speaks in Javanese language rather than Bahasa Indonesia. Just like what the speaker said in the interview "Karena sedikit banyak kan sering toh, bermasyarakat campur sama orangorang kan. Ooo.... Orang ini kalau 
pakai bahasa Indonesiakan iya memang paham tapi ya gimana gitu, jadi kalau pakai bahasa Indonesia campur bahasa Jawa, oo... lebih eee.... Orang ini lebih cocok mendengarkan bahasa ini" (Means "More or less I have experienced to mingle with society. Ooo...if a person speaks in Bahasa Indonesia, other will understand, but it seems strange. So, if I mix Bahasa Indonesia and Javanese language, oo.. more... ee... this person seems better understanding and suitable to listen to it).

4. To understand the social condition of the environment where the speaker read the sermon.

The next factor which causes the speaker mixes the code is Norms of Interaction and Interpretation. This factor means the sermon speaker must speak politely to the older people and to the social environment where the traditional norms are still done. If he only delivers his sermon in Bahasa Indonesia, it seems that he makes his and the listeners' generation is the same. Generation in this case shows the oldness of someone.

5. To make himself accepted by the listener of the sermon.

As part of the sermon community in the Friday prayer sermon, the speaker wants himself and his sermon to be accepted by the listeners. His ways to mix the code, the Javanese language dictions to mix in Bahasa Indonesia, and the way delivering them express his attempt to be accepted by the audiences. It means he was serious to compiled his sermon. He thought about the participants, the setting and the scene of his sermon, the norms of Interaction and Interpretation, the genre, and the act sequence while the word is suitable or not for the listeners. In short, he tried to avoid being refused by listeners because of his sermon created inconvenience and his manner to deliver was inappropriate.

6. To make the speaker delivers the sermon easier in front of the listeners.

In the interview result, there is a dialogue like this:

$\begin{aligned} & \text { Interviewee: } \text { Beda, rasanya lebih nyaman. } \\ & \text { Lebih bisa menempatkan diri } \\ & \text { dan menyesuaikan dengan } \text { situasi (Means "Different, it } \\ & \text { will be more convenient. We } \\ & \text { can place ourselves in the } \\ & \text { right situation") } \\ & \text { Interviewer: Yang mana itu? (Which one } \text { was that?) } \\ & \text { Interviewee: Yang pakai dua bahasa. (The } \\ & \text { one which uses two } \\ & \text { languages) }\end{aligned}$

Those dialogue cutting shows us that the speaker will be more comfortable because he is sure that he understands the situation of his listeners by doing code mixing in his sermon. On the other part of dialogue, we find:

$\begin{array}{clr}\text { Interviewee: } & \text {... basiknya adalah } & \text { orang } \\ \text { Jawa, maka r r rika } & \text { menggunakan } & \text { bahasa }\end{array}$ 
Indonesia terus akan berpindah ke bahasa Jawa. Rasanya itu lebih gampang atau lebih enak. ... (Means "Basically, I am Javanese person. So, if we use Bahasa Indonesia then move to Javanese language. I feel it is easier or more comfortable")

7. To make the sermon language more sociable to be delivered to the people in his village.

As described in the Pendem village profile, we understand that most of Pendem people are using Javanese language in their daily life. Pendem people also understand that by using Kromo Inggil in Javanese language means that the speaker is giving great attention and honor, shows politeness, wants to be paid attention to by the listener, and understands who the speaker speaks to.

8. To make the sermon get in touch to the listeners.

In the sermon we find that the speaker for example uses a Javanese word "Gusti..."(Means, The Great). Actually, in Bahasa Indonesia there is also a word which has the same meaning, which is "Junjungan, Pangeran or Yang Mulia”. But, the speaker mixes and chooses that word in order to show the greatness and familiarity. Greatness means the word "Gusti..." refers to the one who is always given honoured by all people. This word is only suitable to call the name of God. Familiarity means that this word will always be positioned as the adjective which explains the name of God. So, it will be rude to say the name of God in Javanese language without using the word "Gusti...". In short, the speaker mixes the code because of the act sequence factors.

\subsection{The Responses of the Listeners of a}

\section{Friday Prayer Sermon}

The researcher had given some questionnaires to the listeners of a Friday prayer sermon (January3 $\left.1^{\text {st }}, 2020\right)$. There are 25 people who frequently pray and listen to the sermones. The listeners were given 10 questions which were divided into 8 optional questions and 2 short answer questions. There are two short answer questions because the researcher wants to know the response directly and shows that there are 25 different people. These are the result of the questionnaires:

\begin{tabular}{|c|c|c|c|}
\hline No & Statement & Yes & No \\
\hline 1 & $\begin{array}{l}\text { Hearing friday sermon } \\
\text { prayer in Miftahul } \\
\text { Hidayah mosque in } \\
\text { Pendem village }\end{array}$ & 25 & 0 \\
\hline 2 & $\begin{array}{l}\text { Realizing the mixing } \\
\text { code in sermon }\end{array}$ & 21 & 4 \\
\hline 3 & $\begin{array}{l}\text { Understanding the } \\
\text { sermon at the time it is } \\
\text { delivered }\end{array}$ & 20 & 5 \\
\hline 4 & $\begin{array}{l}\text { Agree the mixing code } \\
\text { in sermon }\end{array}$ & 20 & 5 \\
\hline 5 & $\begin{array}{l}\text { Understanding whole } \\
\text { content of sermon }\end{array}$ & 22 & 3 \\
\hline 6 & $\begin{array}{l}\text { Difficult } \\
\text { understanding }\end{array}$ & 5 & 20 \\
\hline
\end{tabular}




\begin{tabular}{llll}
\hline 7 & $\begin{array}{l}\text { Listening same mixing } \\
\text { code sermon practice } \\
\text { in other mosque }\end{array}$ & 14 & 11 \\
\hline 8 & $\begin{array}{l}\text { Hearing positive } \\
\text { responses on such } \\
\text { sermon }\end{array}$ & 15 & 10 \\
\hline 9 & $\begin{array}{l}\text { Preferring delivered } \\
\text { sermon in 2 languages }\end{array}$ & 12 & 13 \\
\hline 10 & $\begin{array}{l}\text { Mix JL+BI easier to } \\
\text { understand than BI } \\
\text { only }\end{array}$ & 12 & 13 \\
\hline
\end{tabular}

From the additional questionnaires, the researcher found that although the listeners understand and know what the content a Friday prayer sermon (January $\left.31^{\text {st }}, 2020\right)$, they tend to listen to Bahasa Indonesia sermones only. The reasons are:

1. "Lebih memasyarakat pakai Bahasa Indonesia (3 persons have similar answer)". This statement shows that listeners care and pay attention to other that not only Javanese people are the listeners of the sermon. So, it is better to use Bahasa Indonesia as the National Language of Indonesia which mostly Indonesian people understand.

2. "Banyak orang pendatang yang hanya mengerti Bahasa Indonesia saja”. This statement supports the previous reason that not all the listeners understand Javanese language. Especially, the speaker used kromo inggil.

3. "Lebih enak saja di dengar, tidak membingungkkan seperti kalau memakai Bahasa Indonesia campur bahasa Jawa". After the researcher asks about his opinion, the listener said that he felt more comfortable when he listened to Bahasa Indonesia sermon only rather than a sermon which used Bahasa Indonesia and Javanese language. Because, he had to think twice when he heard a sentence using Javanese words and Bahasa Indonesia.

4. "Lebih mudah dimengerti" (4 persons have similar answer). This statement shows us that the listeners felt they have better understanding when they heard Bahasa Indonesia sermon. Because in Bahasa Indonesia sermon only, they must understand one language. But not as if they heard a sermon which uses Bahasa Indonesia andJavanese language. Moreover, if there are some who rarely used Javanese word like milo, keranten, etc. which not all Javanese people understand the meaning.

5. "Sebetulnya dua-duanya tidak apaapa, tapi kan tidak semua orang suka khutbah menggunakan campuran Bahasa Indonesia dan Bahasa Jawa”. This statement also supports the listener opinion that not all the listeners understand Javanese language. Respondents also thought that it will be dangerous while the listeners' interprete the sermon in wrong way because of wrong interpretation of the meaning of a word, phrase, clause, or sentence. Moreover, the thing that is 
discussed in the sermon is about religion.

Regarding the aforementioned findings of this research, the followings are the elaboration of the theories of code mixing with the data findings.

According to Holmes (2001) code mixing suggests that the speaker mixes up code because of incompetence, whereas the switches are very well-motivated in relation to symbolic or social meanings of two codes. So, they use code mixing because they want their listeners looked interesting, friendly, and understandable, and make them closer with someone else. Based on this theory and the comparison with the result of code-mixing research, researcher understood that the speaker of the sermon did not think first when and where he had to mix the code. Moreover, the researcher also found difficulties to identify whether the speaker mixed the code in form of words, phrases, clauses, or sentences. The point is, the speaker mixed the code to make his listeners interested and accept his sermon.

Then, according to Redlinger and Park in Hoffman (1991) characteristic of code mixing is the combination of words or phrases or larger units. It means that they mix their words, phrases, clauses, sentences between native language and second language. In addition, the theory was implemented by the speaker of the sermon when the researcher saw on the result of the analysis, code mixing which happened are in the form of words, phrases, clauses, and also sentence.

The findings on the type of code mixing that occurred in the Friday prayer sermon also supported the previous research done by Ramadhan (2017), Prasetyo (2014), Dewi et. al. (2017), Kustati (2014), and Pratama (2014) that the code mixings appeared in intra-sentential and intersentential. While, this research showed additional form of code mixing occurance that was in the level of phrase.

Discussing the Factors that Influence the Speaker to Mix the Code, there are many factors why the speaker mixes the code. According to Hymes (in Wardhaugh, 2002) there are eight factors which can cause the speaker to mix the code. While according to Tripp (in Grosjean, 1982), there are only four factors which cause the speaker to mix the code. As the result, the researcher will use Hymes' theory because her theory is more detail and make the researcher observes them easier the factors of someone's causes mix the code.

From the data analysis, the factors that influence the characters to mix the code are: the setting and scene, the participants, ends, act sequence, instrument, norms of interaction and interpretation, and genre.

First, the setting and scene influence the sermon speaker to mix the code. It is proved that he observes the environment where he will deliver his sermon first and 
what language which the people mostly use. In addition, his background that lives in Javanese family influences his language so that he feels more comfortable to mix the language in his sermon. Then, he prefers to make his listeners feel comfortable too to listen to his sermon while mostly the listeners speak Javanese language. Finally, the sermon speaker's believe that by mixing his language, his sermon is considered more polite than if he only uses Bahasa Indonesia only. Kartomiharjo (1979) explains in an example of using code mixing to show intimacy and politeness in a conversation between Javanese (J) and non-Javanese (NJ) below:

NJ : Lambat atow cepat asal empat taon, seng orang terpaksa dibawa aros ke sana-ke mari

The word "seng" is actually Javenese language which is used by nonJavanese to show his intimacy to speak with Javanese. Hence, intimacy in code mixing may help speaker to show politeness and formality to listeners as the speaker uses formal words, phrases, or clauses from one language to mix the other language. It also means that the speaker who mixed the code in Friday sermon want to show his intimacy and being polite to listeners.

Second, the sermon speaker pays big attention to the participants of his sermon. The speaker considered a lot to whom they speak (Ramadhan, 2017). His reason why he has to mix his Bahasa Indonesia sermon with Javanese language because of the language which is used by the listener of the sermon mostly is Javanese language, some of them are old and rarely use Bahasa Indonesia, he has to speak politely in his sermon to the older man, and he wants his listeners to easily listen to and understand his sermon. In the end, the sermon speaker gets the attention of his listeners. The unique thing regarding this factor was in Budi et. al. (2017) research. It stated that since many Kaskus.com users would not grab the messages if the speaker used code mixing, the speaker used it less.

Third, the end is also the target which the sermon speaker wants to grab. The speaker wants the listeners to pay attention and listen seriously to the sermon which is delivered (Ramadhan, 2017; Prasetyo, 2014). The speaker considered the function of his sermon. The sermon speaker wants a change in his listeners because of easily understanding the sermon so that they know what to do to their life.

Fourth, the speaker was influenced by the act sequence factors while he was creating the sermon. As has been explained in analysis, the sermon speaker likes to add word "Gusti.." which means the greatest of the great. He adds that because the name of God will be more meaningful if he adds "Gusti..." and this word will only suitable for the name of God and only in Javanese language. This situation also appeared in Fadila (2016) and Kustati (2014) researches 
as the speaker did not find best suit translation for certain term in sermon.

Fifth, Friday prayer sermon is a formal sermon and serious so that it shows one factor, key, causes the speaker mixes Javanese language into Bahasa Indonesia sermon.

Sixth, the sermon is delivered in two language is because the sermon speaker want himself easily delivers his sermon. Besides, he thinks that his language and family background is Javanese. In spite of he wants the listeners feel convenient and enjoy his sermon, the speaker also wants him fluent, comfortable, and enjoy the sermon. In the interview result, we also know that the using of Javanese language influences him to be accepted by the listeners. Also, mixing the language makes the intonation he uses in his sermon better. So, Javanese language is the instrument for the speaker to make his sermon and himself better.

Seventh, the next factor which causes the sermon speaker to mix the languages is norms of interaction and interpretation. The speaker always pays attention to the politeness of his sermon language because some of the sermon listeners are older, more well-educated, rarely use Bahasa Indonesia than he is. Also, he has to respect everyone who listens to the sermon. He also understands that he lives in a traditional environment which still uses social norm and rule. So, his sermon must be heard polite. Then, he mixes his sermon with Kromo Inggil.

The last, Friday prayer sermon sermon is a religious sermon. Absolutely, the way the sermon speaker delivers the sermon must be taken into consideration. The material, the language, the costume, the manner of the speaker, and some other rules must be considered. In this case, the sermon speaker understands that the genre of his sermon makes him to show that his religion is flexible and not strict through his sermon.

In addition, the researcher found that the speaker's social and educational background play big role and often causes him use Javanese language. From the interview the researcher know that he always takes Islamic schools and he has lived in Islamic boarding house or Pondok Islam. In Pondok Islam he learns Kitab or Islamic book guide in Arabic and Javanese with his Ustadz or his teacher. Also, because the book is written in Arabic and the meaning is in Javanese language (Kromo Inggil). Only sometimes his teacher uses Bahasa Indonesia. In addition, when he speaks to his friends, he has to speak Bahasa Indonesia because many of his friends cannot speak Javanese. This fact shows that his capability to speak Javanese mixed to Bahasa Indonesia because he is accustomed by the way he speaks like that to his friends.

The researcher has found some reasons which is compiled based on the 
factors defined by Hymes. But, the researcher still does not know exactly in what way or when the speaker of the sermon must mix the code. There is no clear answer from the speaker during the interview. The point is he mixes the code because he wants to make himself and listeners comfortable with his sermon.

This research shows that Hymes theory can explain in more details than Tripp theory while discussing the factors influencing someone to mix the code. Then, this research also supports the previous study by Nurindrawati (2006), who focused her research on "Code Mixing Demonstrated by the characters in the Novel Cintapucino" She believes that the characters in that novel use code mixing because of their educational background. Prasetyo (2014) stated that SBY as the president of Indonesia realized his status which influenced his use of code mixing during his sermon. In this case, the researcher knew that the ability of the speaker to mix the code is mostly influenced by the way he spoke to other friends in pondok, the way he should deliver sermon in by using code mixing in pondok, also the way he learned kitab in pondok which were delivered in kromo inggil and Bahasa Indonesia by his teacher or ustadz.

There are also responses from the listeners about the use of code mixing in that sermon. Based on the analysis, the researcher believes that although the speaker has positive purpose for the listeners of his sermon, he must remember that not all of the listeners prefer to listen to a sermon which mixing two languages (Javenese language into Bahasa Indonesia). This might be what Kaskus.com users thought about using code mixing in chatting (Budi et. al., 2017). However, mostly the listeners still understand a Friday Prayer Sermon (January $31^{\text {st }}, 2020$ ).

\section{Closing}

The researcher found that there are some code-mixing elements used in a Friday Prayer Sermon (January $31^{\text {st }}, 2020$ ) consisting of word, phrase, clause and sentence. Those elements are explained below:

Code Mixing elements in a Friday Prayer Sermon (January3 $1^{\text {st }}, 2020$ )

Word : maksudtipun (means); senaoso (although); soho (also); etc.

Phrase : dumateng ngarsanipun (to the majesty); monggolah kito (let us together); etc.

Clause : ugi nebihi larangan-laranganipun (also avoid the prohibited things); kalian sampun dipun ciptaaken menungso (As the creation of human beings);

Then, the researcher found that there are eight reasons why the speaker mixed the code (Bahasa Indonesia sermones is mixed with Javanese language) in his sermones as 
the researcher got from the interview. The reasons are: (1) To make the listeners listen more easily his sermon, (2) To make his sermon accepted by the listener, (3) To understand the listener that some old man will feel comfortable if the sermon is delivered in Javanese language, (4) To understand the social condition of the environment where the sermon speaker read the sermon, (5) To make himself accepted by the listener of the sermon, (6) To make the speaker deliver the sermon more easily in front of the listeners, (7) To make the sermon language more sociable to be delivered to the people in his village, and (8) To make the sermon get in touch with the listeners.

Finally, the researcher knew that although 22 respondents who were given questionnaires said they knew and understood a Friday Prayer Sermon (January $31^{\text {st }}, 2020$ ) was delivered in two languages that were Bahasa Indonesia and Javanese language, 10 of that 22 respondents who were the listeners needed that the sermones should be delivered in Bahasa Indonesia only. It is because some of them feel more comfortable, easier to be listened, and easier to be understood if the sermon is delivered in Bahasa Indonesia only. Then, those 10 people agreed that the sermon should be delivered in Bahasa Indonesia in regard to the listeners that they were not only coming from Pendem village who mostly understood Javanese language.
Despite the finding of this research, there are still many items that are not taken into account in this research in order to get more comprehensive and better finding. The future research is expected to dig more understanding on code mixing phenomenon in different social event such as in daily ineraction. Also, employing different languages in code mixing will create more pedagogical insight on how words are mixed.

\section{References}

Brice, A. (1999). Code Switching and Code Mixing in Children Directed Language. http: //www.asha.ucf.edu/Fullerton99.ht $\mathrm{ml}$

Budi, A. H., Azhar, F., \& Dahnilsyah. (2017). A Descriptive Study of Code Mixing Form in Kaskus Online Forum. JOM, 4(2), 1-7.

Creswell, J. W. (2016). Qualitative Inquiry and Research Design. Sage Publications.

Dewi, K Sintya; Amelia, Mashita; Suarnajaya, I. W. (2017). An Analysis of Code Mixing Used in Instagram by the Students of English Language Education. Jurnal Pendidikan Bahasa Inggris Undiksha, 5(2). https://ejournal.undiksha.ac.id/inde x.php/JPBI/article/view/14930

Fadila. (2016). Code Mixing Found in Debatesof Indonesian President Candidates 2014. Bahasantodea, 4(3). 20-27 
Fasold, R. (1984). The Sociolinguistics of Society. Blackwell.

Fraenkel, G. (1982). What is Language? Gina and company.

Grosjean, F. (1982). Life with Two Languages. Harvard University Press.

Gumperz, J. (1982). Language in Social Groups. Stanford University Press.

Hanif. (2016, 5 September). Khuthbah Idul Adha - Bahasa Jawa. Accessed on 23 October 2020, from http://alukhuwah.com/2016/09/05/k huthbah-iedul-adhaa-bahasa-jawa/

Hoffmann, C. (1991). An Introduction to Billingualism. Longman.

Holmes, J. (2001). An introduction to Sociolinguistics. Longman.

Hudson, R. A. (2012). Sociolinguistics. Cambridge Press.

Kartomihardjo, S. (1979). Etnography of Communicative Codes in East Java. Cornell University.

Kimberley, A. N. (2016). The content Analysis Guidebook. New York: SAGE.

Kustati, M. (2014). An Analysis of Code-Mixing and Code-Switching in EFL Teaching of Cross Cultural Communication Context. $A L-T a$ Lim, 21(3), 174. https://doi.org/10.15548/jt.v21i3.10

Nababan, S. (1997). Psikolinguistik Suatu Pengantar. PT. Gramedia.

Nurindrawati. (2006). Code Mixing
Demonstrated by the Characters in the Novel Cintapicino. Brawijaya University.

Pratama, Y. W. (2014). Code Mixing on the Dialogue of "9MM" Mobile Game by Gameloft. Thesis. Universitas Brawijaya Malang

Prasetyo, D. I. A. (2014). Code Mixing And Switching in the Opening Sermon of Susilo Bambang Yudhoyono in the International Conference for Anti-Corruption Agencies. Thesis. Universitas Brawijaya Malang

Ramadhan, N. G. (2015). Code Mixing and Code-Switching Analysis in Ranah 3 Warna Novel by Ahmad Fuadi. Thesis. Universitas Diponegoro

Saville-Troike. (2008). The Etnography of Communication: An Introduction (Oxford). Basil Blakwell.

Styaningsih. (2005). A Study of Code Mixing in the Novel "Ca-Bau-Kan" by Remy Sylado. Brawijaya University.

Teguh, I. (2019, 18 July). Bahasa Daerah Kian Tersingkir oleh Bahasa Indonesia, Kok Bisa?. Accessed on 23 October 2020, from https://tirto.id/bahasa-daerahkian-tersingkir-oleh-bahasaindonesia-kok-bisa-eev5

Wardhaugh, R. (2002). An Introduction to Sociolinguistics Third Edition. Blackwell. 